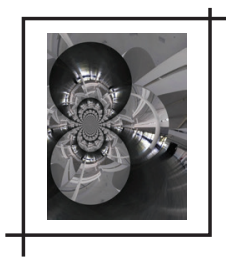

\title{
O RETORNO DA CRIATIVIDADE: ENTREVISTA COM MICHEL MAFFESOLI ${ }^{1}$
}

Trama Interdisciplinar: 0 senhor falará no Mackenzie sobre a "vida como obra de arte" e 0 "retorno da criatividade". Em entrevistas anteriores, o senhor falou da associação entre o ócio (otium) e o desejo de criatividade. 0 senhor poderia nos explicar como funciona essa relação?

Michel Maffesoli: Considerar "a vida como uma obra de arte" é reconhecer que uma mutação fundamental está ocorrendo. Uma era está chegando ao fim: a modernidade, uma outra está começando, aquela que, por falta de algo melhor, e eu sou um deles, é denominada como pós-modernidade. Não esqueçamos que os "tempos modernos", que começaram no século XVIl e terminaram em meados do século XX, foram caracterizados por uma concepção puramente utilitarista do mundo. "Só vale o que é útil" era o slogan essencial daquela época. 0 que é causa e efeito de tal concepção é a valorização progressiva do trabalho. Até o século

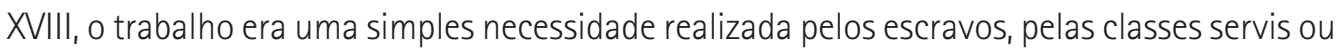
pelo povo, todas as categorias que não participavam da direção da sociedade. E foi no final do século XVII que o trabalho, para usar a expressão de Kant, tornou-se um "imperativo categórico", permitindo que todos se realizassem, realizassem suas vidas e contribuissem para a realização de um mundo onde a economia prevalecesse. É assim que veremos K. Marx, em 0 capital, falar de "valor trabalho".

Parece-me que esse tempo está chegando ao fim. Assim, a palavra trabalho já não permite mobilizar a energia das novas gerações, enquanto a própria ideia de criaçao, associada à da criatividade, encontra uma força e um vigor inegáveis.

Em uma palavra, além ou abaixo do utilitarismo ou quantitativismo, é a qualidade da existência que prevalecerá cada vez mais. Isso equivale a "não mais perder a vida para ganhá-la", mas a restaurar a nobreza do festivo, do lúdico, do onírico, como parâmetros essenciais de qualquer existência individual e coletiva.

Trama Interdisciplinar: 0 senhor afirma ter se inspirado em 0 nascimento da tragédia, de Nietzsche, para pensar sobre a "vontade de tornar nossas vidas obras de arte". De acordo com

1 - Tradução de Ana Paula Silva Moreno. 
a sua concepção, todos os seres humanos podem transformar as suas vidas em obras de arte? Qual é a diferença entre essa concepção daquela de Andy Warhol, na qual "In the future, everyone will be world-famous for 15 minutes"?

Michel Maffesoli: Nós podemos, na verdade, entender que a fórmula bem conhecida e judiciosa de Andy Warhol pode ser considerada como parte da mutação profunda em curso. Mas é apenas uma "fórmula"! De modo profético, Nietzsche tinha sentido e analisado muito mais profundamente que aquilo que Heidegger chamaria mais tarde de simples "utensilidade" já não era o valor essencial. 0 retorno do espiritual, do cultural como fundamento de toda a vida social começa naquele momento. A necessidade é completada pelo desejo. É assim que as gerações mais jovens em particular, mas de um modo mais geral a sociedade no seu conjunto, irão atribuir uma importância crescente ao bem-estar. Ou ao que se pode chamar de "preço das coisas sem preço".

É a importância dada à arte, espalhando-se por toda a vida cotidiana, que melhor caracteriza o espírito da era pós-moderna. A partir daí, a arte tornou-se um "imperativo atmosférico". Um novo clima do qual nada nem ninguém pode escapar. A esse respeito, é interessante notar que os próprios líderes empresariais são obrigados na gestão a integrar elementos que já não são simplesmente racionais, mas que irão privilegiar a totalidade da vida: espaços de trabalho "estetizados", momentos dedicados ao convívio, importância dada aos sentimentos etc. Todos são expressões da arte vivida na vida quotidiana.

Trama Interdisciplinar: 0 conceito de "criatividade" é bastante controverso. Nos dias de hoje, ela pode tomar feições como a domesticação sutil em nome de um homem ideal e dócil. Isso pode ser percebido na oficinas de cerâmica, de textos e performances artísticas que geralmente são consideradas espaços de "criatividade". Se nos inspirarmos em Nietzsche, para quem a potência da força criativa estaria na tentativa de libertar o homem das pressões reguladoras tradicionais da sociedade, como o senhor concebe a sociedade criativa do pós-moderno?

Michel Maffesoli: Certamente, pode haver uma forma de "recuperação" ou "mercantilização" dessa criatividade. Mas podemos considerar que essa "domesticação" é uma forma de reconhecimento do caráter intransponivel e do regresso em força da criatividade.

Além disso, considero que uma das especificidades da existência humana é o que denominei, no meu livro A conquista do presente (2001), a astúcia. É como se estivéssemos sujeitos ao economicismo dominante, e isso ocorre porque é necessário ganhar a vida, mas somos astutos com o sistema econômico. Introduzem-se, sub-repticiamente, modos de ser, formas de vida que curto-circuitam a simples ordem econômica.

Podemos, além disso, pensar que é porque existe uma astúcia que, em longo prazo, a vida pode durar. Recordemos, a esse respeito, que as civilizações passadas são lembradas de acor- 
do com aquilo que trouxeram à arte: monumentos, literatura, pintura, escultura e outras formas de criatividade!

Trama Interdisciplinar: Na chamada "indústria criativa", os novos pactos de trabalho se dão a partir da ideia de que a criatividade se realizou por meio do capital. Ou seja, se a força criativa existiu, é porque ela deu lucro. Um exemplo são as start-ups que prosperam e aquelas que desaparecem (uma pode ter sido considerada "criativa" e outra não suficientemente criativa). Nesse contexto, como dar credibilidade e legitimidade à ideia de "criatividade"?

Michel Maffesoli: Dito de uma forma brutal, ou mesmo obscena, se não conseguirmos mobilizar, em longo prazo, a energia juvenil sobre a própria palavra de trabalho, poderemos fazer alguém trabalhar 18 horas por dia sobre a ideia de criatividade, o que pode parecer um paradoxo.

Mas as start-ups que continuam, e até crescem, são aquelas que conseguiram mobilizar a criatividade dos parceiros. Repito, o jogo, o sentimento de celebração, a importância dos sonhos são todos elementos que contribuem para o sucesso dessas empresas emergentes. Em suma, o que estamos experimentando é o retorno de uma concepção holística da existência. A modernidade enfatizou a separação entre natureza e cultura, corpo e mente, corpo e espírito, material e espiritual, o oposto está acontecendo. É a reversibilidade, a interação desses vários aspectos da vida humana que é cada vez mais prevalente. Em suma, o prazer não é mais adiado para o dia seguinte. Ele é repatriada para o presente.

0 que, recordo, foi uma especificidade de grandes momentos culturais: por exemplo, o italiano Quattrocento ou o Renascimento francês... É uma metamorfose tão grande que, do meu ponto de vista, está acontecendo diante dos nossos olhos.

Trama Interdisciplinar: 0 senhor pensa que há uma "força criadora" do bem e também uma do mal ou ela está sempre "além"?

Michel Maffesoli: Por outras palavras, de uma forma nietzschiana, a força criadora está "para além do bem e do mal"! Moralismo nunca é um bom conselheiro. Nietzsche, ironicamente, até falou da "moralina"2. A criatividade expressa, no sentido mais forte do termo, a vitalidade,

2 - A expressão das Moralin do alemão foi traduzida para o francês como moraline e tem sido usada no português como "moralina". Friedrich Nietzsche usou a expressão (das Moralin) para ridicularizar a moralidade do bom pensamento. 0 sufixo "ina" de moralina está ligado à "moral" para sugerir uma substância farmacêutica de um produto imaginário capaz de produzir uma "boa moralidade" do sujeito afeito a dar lições de moral ou ao terrorismo intelectual. Um exemplo seria a citação: "virtude à maneira da Renascença, virtù, virtude livre de moralina". Cf. Nietzsche, F. O anticristo: maldição ao cristianismo. Tradução Paulo César de Souza. São Paulo: Companhia das Letras, 2007. 
mesmo o vitalismo que caracteriza a nossa espécie animal. Ela restaura uma inegável atualidade da "filosofia da vida" que a modernidade negou ou marginalizou em nome do simples racionalismo. Raciocínio mórbido, se é que alguma vez houve um.

Pela minha parte, ao enfatizar a totalidade, gostaria de lembrar que é a "razão sensível" que está recuperando um vigor inegável, um Elogio da razão sensive ${ }^{\beta}$. Isso é o que constitui o coração pulsante de toda a criatividade. 